\title{
PENGARUH PERSEPSI SISWA TENTANG PENGGUNAAN METODE PEMBELAJARAN GURU TERHADAP AKTIVITAS BELAJAR PENGETAHUAN PRODUK PADA SISWA KELAS XI JURUSAN PEMASARAN DI SMK N 1 SINGARAJA TAHUN AJARAN 2017/2018
}

\author{
Dewa Ayu Apri Mulianti \\ Jurusan Pendidikan Ekonomi \\ Universitas Pendidikan Ganesha \\ Singaraja, Indonesia \\ e-mail: aprimulianti12@gmail.com
}

\begin{abstract}
Abstrak
Penelitian ini bertujuan untuk mengetahui persepsi siswa tentang penggunaan metode pembelajaran guru, aktivitas belajar siswa dan pengaruh persepsi siswa tentang penggunaan metode pembelajaran guru terhadap aktivitas belajar pengetahuan produk pada siswa kelas XI Jurusan Pemasaran di SMK N 1 Singaraja. Jenis penelitian ini adalah penelitian kausal. Teknik pengambilan sampel yang digunakan adalah proportional random sampling dengan jumlah sampel sebanyak 100 sampel. Metode pengumpulan data yang digunakan adalah kuesioner dan lembar observasi. Data yang telah didapatkan kemudian dianalisis dengan menggunakan analisis deskriptif kuantitatif dan uji $t$ dengan bantuan SPSS versi 16.00. Hasil penelitian menunjukkan bahwa persepsi siswa tentang penggunaan metode pembelajaran guru berada pada kategori cukup baik dengan persentase sebesar 39\%, aktivitas belajar siswa tergolong dalam kategori aktif dengan persentase sebesar $69 \%$, dan terdapat pengaruh yang signifikan antara persepsi siswa tentang penggunaan metode pembelajaran terhadap aktivitas belajar yang ditunjukkan dengan nilai signifikansi sebesar $0,000<0,05$ dan nilai koefisien diterminasi sebesar 0,668 artinya $66,8 \%$ aktivitas belajar siswa dipengaruhi oleh persepsi siswa tentang penggunaan metode pembelajaran guru sedangkan sisanya sebesar $33,2 \%$ dipengaruhi oleh faktor lain.
\end{abstract}

Kata Kunci: persepsi siswa tentang penggunaan metode pembelajaran guru, aktivitas belajar

\begin{abstract}
Research aims to understand student's perception about the use of teacher learning methods student's learning activities, and the influence student's perception about the use of teacher learning methods to student's learning activities in class XI of Marketing departement in SMK N 1 Singaraja. The kind of research used is causility. Sampling technique used proportional random sampling with total sample 100 sample. The data collection method used is questionnaire and observation sheet. The data analyzed with quantitative descriptive analysis and t tes with program SPSS 16. The research results present that student's perception about the use of teacher learning methods being on category enough with percentage of $39 \%$.Student's learning activities be in active category with percentage of $69 \%$. Student's perception about the use of teacher learning methods influential significantly to student's learning activities with the results of $t$ test the $p$-value $0,000<0,05$. The value of the coefficients determined adjusted 0.668 it means $66.8 \%$ student's learning activities influenced by the student's perception about the use of teacher learning methods while the rest of $33,2 \%$ influenced by others factors.
\end{abstract}

Keywords: student's perception about the use of teacher learning methods,student's learning activitie

\section{PENDAHULUAN}

Proses belajar mengajar dikatakan berhasil apabila tujuan pembelajaran yang telah ditetapkan dapat tercapai. Salah satu cara yang digunakan oleh guru untuk mencapai tujuan pembelajaran adalah 
dengan menggunakan metode pembelajaran yang tepat sesuai dengan materi, tujuan pembelajaran, dan karakteristik masing-masing siswa. Dengan penggunaan metode pembelajaran yang tepat diharapkan tercipta kegiatan belajar mengajar yang aktif, interaktif, kreatif, efektif dan menyenangkan. Proses pembelajaran yang aktif bukan semata-mata hanya mentransfer pengetahuan dari guru ke siswa, tetapi juga melibatkan siswa untuk berpartisipasi secara aktif dalam kegiatan pembelajaran. Aktivitas belajar siswa merupakan prinsip utama dalam proses pembelajaran, tanpa adanya aktivitas proses belajar mengajar tidak akan berjalan dengan baik. Aktivitas belajar yang dimaksud tidak hanya terbatas pada aktivitas fisik saja, melainkan meliputi aktivitas yang bersifat psikis atau mental. Menurut Sardiman (2011:95), "aktivitas belajar adalah segala pengetahuan yang diperoleh dengan pengamatan sendiri, penyelidikan sendiri, dengan bekerja sendiri baik secara rohani maupun teknik". Tak pernah terlihat orang belajar tanpa melibatkan aktivitas raganya. Apalagi bila aktivitas belajar itu berhubungan dengan menulis, mencatat, membaca, mengingat, berfikir, latihan atau praktek dan lain sebagainya. Aktivitas belajar yang dapat dilakukan siswa selama mengikuti proses pembelajaran dapat bermacam-macam.

Menurut Diedrich (dalam Hamalik, 2009), aktivitas belajar dapat digolongkan menjadi 8 (delapan) aktivitas belajar. Kedelapan aktivitas belajar tersebut adalah visual activities, seperti, membaca, memerhatikan gambar demonstrasi, percobaan, pekerjaan orang lain, oral activities, seperti menyatakan, merumuskan, bertanya, memberi saran, mengeluarkan pendapat, mengadakan wawancara, diskusi, interupsi, listening activities, seperti mendengarkan, percakapan, musik, pidato, writing activities, seperti menulis cerita, karangan, laporan, angket, menyalin, drawing activities, seperti menggambar, membuat grafik, peta, diagram, motor activities, seperti melakukan percobaan, membuat konstruksi, model, meraparasi, bermain, berkebun, berternak, mental activities, yaitu menanggapi, mengingat, memecahkan soal, menganalisis, melihat hubungan, dan mengambil keputusan, dan emotional activities, yaitu menaruh minat, merasa bosan, gembira, semangat, bergairah, berani tenang, gugup.

Setiap siswa memiliki aktivitas belajar yang berbeda, ada siswa yang memiliki aktivitas belajar yang tinggi, tetapi ada juga siswa yang memiliki aktivitas belajar yang rendah, hal ini dipengaruhi oleh persepsi masing-masing siswa (Suryabrata, 2004). Persepsi merupakan suatu pengamatan tentang objek atau peristiwa. "Objek yang dapat dipersepsi sangat banyak, yaitu segala sesuatu yang ada di lingkungan manusia" (Walgito, 2010:96). Salah satu objek yang dapat dipersepsi oleh siswa adalah metode pembelajaran yang digunakan oleh guru. Persepsi berasal dari kata "perception" yang berarti tanggapan, daya memahami, atau menanggapi sesuatu yang diawali dengan penginderaan kemudian ditransfer ke otak. Menurut Kamus Besar Bahasa Indonesia persepsi diartikan sebagai tanggapan dari sesuatu. Robbins \& Judge (2002:19) menyatakan bahwa, "persepsi adalah proses dimana individu mengatur dan menginterpretasikan kesan-kesan sensoris mereka guna memberikan arti bagi lingkungan mereka". Persepsi mempunyai peranan yang penting dalam kehidupan manusia karena dapat dijadikan pedoman dalam bertingkah laku. Slameto (2003) menyatakan, persepsi adalah proses yang menyangkut masuknya pesan atau informasi ke dalam otak manusia. Melalui persepsi manusia terus menerus mengadakan hubungan dengan lingkungannya. Hubungan ini dilakukan lewat indranya, peraba, perasa, dan pencium. Selanjutnya, menurut Walgito (2010:87) "persepsi merupakan suatu proses yang didahului oleh proses penginderaan, yaitu merupakan proses diterimanya stimulus oleh individu melalui alat indera atau disebut juga proses sensori" Melalui persepsi, seseorang dapat berhubungan melalui inderanya yaitu indera penglihatan, pendengaran, 
peraba, perasa, dan pencium dengan lingkungannya secara berkelanjutan.

Persepsi seseorang terhadap suatu objek tidak terjadi begitu saja, tetapi terbentuk melalui proses-proses yang saling berhubungan. Menurut Walgito (2010:90) proses terjadinya persepsi adalah sebagai berikut. "berawal dari objek yang menimbulkan rangsangan dan rangsangan tesebut mengenai alat indra atau reseptor. Proses ini dinamakan proses kealaman (fisik). Kemudian rangsangan yang diterima oleh alat indra dilanjutkan oleh syaraf sensoris ke otak. Proses ini dinamakan proses fisiologis. Selanjutnya terjadilah suatu proses di otak, sehingga individu dapat menyadari apa yang ia terima dengan reseptor itu, sebagai suatu rangsangan yang diterimanya. Proses yang terjadi dalam otak/pusat kesadaran itulah dinamakan dengan proses psikologis. Dengan demikian taraf terakhir dari proses persepsi ialah individu menyadari tentang apa yang diterima melalui alat indra (reseptor)". Adapun objek yang dapat dipersepsi oleh siswa adalah penggunaan metode pembelajaran guru. Metode merupakan salah satu komponen pendidikan yang sangat penting. Guru dalam proses pembelajaran harus memperhatikan penggunaan metode yang tepat sesuai dengan karakteristik bidang studi. Oleh karena itu, guru hendaknya mengetahui dan memahami berbagai macam metode pengajaran, baik kelebihan maupun kelemahanya. Menurut Sanjaya (2011:147) "metode pembelajaran adalah cara yang digunakan untuk mengimplementasikan rencana yang sudah disusun dalam kegiatan nyata agar tujuan yang telah disusun tercapai secara optimal". Selanjutnya Slameto (2003) menyatakan bahwa "metode pembelajaran adalah suatu cara/jalan yang harus dilalui di dalam mengajar". Menurut Sudjana (2005: 76) "metode pembelajaran adalah suatu cara yang dipergunakan oleh guru dalam mengadakan hubungan dengan siswa pada saat berlangsungnya pengajaran". Apabila guru dapat memilih metode yang tepat disesuaikan dengan bahan pengajaran, murid, situasi, kondisi, media pengajaran, semakin berhasillah tujuan pengajaran yang dicapai. Seorang guru yang profesional biasanya menggunakan lebih dari satu metode sesuai dengan materi yang akan disampaikan. Dalam mengajar banyak sekali metode pembelajaran yang dapat digunakan oleh guru. Metode merupakan salah satu komponen pendidikan yang sangat penting. Guru dalam proses pembelajaran harus memperhatikan penggunaan metode yang tepat sesuai dengan karakteristik bidang studi. Oleh karena itu, guru hendaknya mengetahui dan memahami berbagai macam metode pengajaran, baik kelebihan maupun kelemahanya. Sehingga dapat menentukan metode pembelajaran yang tepat.

Menurut Sanjaya (2011:147) "metode pembelajaran adalah cara yang digunakan untuk mengimplementasikan rencana yang sudah disusun dalam kegiatan nyata agar tujuan yang telah disusun tercapai secara optimal". Selanjutnya Slameto (2003) menyatakan bahwa "metode pembelajaran adalah suatu cara/jalan yang harus dilalui di dalam mengajar". Menurut Sudjana (2005:76) "metode pembelajaran adalah suatu cara yang dipergunakan oleh guru dalam mengadakan hubungan dengan siswa pada saat berlangsungnya pengajaran". Apabila guru dapat memilih metode yang tepat disesuaikan dengan bahan pengajaran, murid, situasi, kondisi, media pengajaran, semakin berhasillah tujuan pengajaran yang dicapai. Seorang guru yang profesional biasanya menggunakan lebih dari satu metode sesuai dengan materi yang akan disampaikan. Dalam mengajar banyak sekali metode pembelajaran yang dapat digunakan oleh guru. Menurut Djamarah \& Aswan (2006) macam-macam metode pembelajaran adalah metode ceramah, metode diskusi, metode tanya jawab, metode resitasi (penugasan), metode kerja kelompok, metode demonstrasi dan eksperimen, metode sosiodrama ( role playing), metode problem solving, metode latihan, metode karyawisata, dan metode simulasi. 
Persepsi siswa tentang penggunaan metode pembelajaran guru dapat berbeda-beda. Perbedaan ini dikarenakan oleh karakteristik masing-masing siswa. Apabila siswa memiliki persepsi yang baik tentang penggunaan metode pembelajaran guru akan cenderung lebih aktif dalam kegiatan belajar mengajar, namun apabila siswa memiliki persepsi yang kurang baik, siswa tersebut akan cenderung merasa bosan saat belajar di kelas, tidak memperhatikan materi yang disampaikan oleh guru, dan kurang terlibat aktif dalam kegiatan belajar mengajar.

Di SMK N 1 Singaraja khususnya kelas XI Jurusan Pemasaran mempunyai kemampuan yang berbeda-beda dalam menerima materi pembelajaran pengetahuan produk, sehingga dalam menyampaikan materi guru pengetahuan produk menggunakan berbagi macam metode pembelajaran. Metode pembelajaran yang digunakan dalam mata pelajaran pengetahuan produk adalah metode ceramah, tanya jawab, diskusi dan penugasan. Metode pembelajaran yang berbeda-beda ini digunakan oleh guru dengan tujuan agar siswa tidak bosan dalam belajar. Pada kenyataannya meskipun guru telah menggunakan berbagai metode pembelajaran, namun aktivitas belajar masih kurang optimal. Hal ini terlihat dari jalannya proses pembelajaran, yaitu pada saat guru menggunakan metode ceramah masih terdapat siswa yang berbicara dengan temannya, dan pada saat diskusi masi didominasi oleh siswa yang aktif atau yang menonjol saja.

$\mathrm{Hal}$ ini diperkuat kembali dengan observasi yang peneliti lakukan di SMK N 1 Singaraja terlihat pada saat proses pembelajaran berlangsung terdapat 30\% siswa yang kurang memperhatikan penjelasan dari guru, beberapa siswa kurang aktif dalam kegiatan belajar mengajar, dan siswa mengganggap bahwa guru hanya menggunakan metode ceramah saat menyampaikan materi. Selain itu guru mata pelajaran pengetahuan produk di kelas XI Pemasaran menyatakan bahwa, siswa masih membaca buku atau catatan pada saat guru menerangkan materi pelajaran, sehingga siswa tidak mendengarkan penjelasan guru dengan baik, siswa masih takut dalam bertanya dan mengemukakan pendapat karena kurangnya rasa percaya diri yang dimiliki. Partisipasi siswa belum menyeluruh, hal ini menyebabkan kesenjangan antara siswa yang aktif dengan yang kurang aktif. Siswa yang aktif dalam kegiatan belajar mengajar cenderung aktif dalam bertanya dan menggali informasi dari guru maupun sumber belajar lain, sementara siswa yang kurang aktif hanya menerima pengetahuan yang datang padanya dan malas untuk mencari informasi dari guru maupun sumber belajar lain, hal ini menunjukkan aktivitas belajar pengetahuan produk siswa kelas XI Jurusan Pemasaran rendah.

Berdasarkan rumusan masalah diatas, maka tujuan penelitian ini adalah untuk mengetahui persepsi siswa tentang penggunaan metode pembelajaran guru pengetahuan produk pada kelas XI Jurusan Pemasaran di SMK N 1 Singaraja tahun ajaran 2017/2018 dan untuk mengetahui aktivitas belajar pada siswa kelas XI Jurusan Pemasaran di SMK N 1 Singaraja tahun ajaran 2017/2018, serta untuk mengetahui apakah terdapat pengaruh antara persepsi siswa tentang penggunaan metode pembelajaran guru terhadap aktivitas belajar pada siswa kelas XI Jurusan Pemasaran di SMK N 1 Singaraja tahun ajaran 2017/2018.

\section{METODE}

Penelitian ini dilaksanakan dengan menggunakan rancangan penelitian expost facto. Menurut Agung (2005), penelitian expost facto adalah penelitian yang menggunakan suatu pendekatan, dimana gejala (objek) yang diteliti telah ada secara wajar tanpa perlu melakukan eksperimen untuk memunculkan variabel (objek) yang ingin diteliti. Tujuan dari penelitian expost facto adalah mencari pengaruh variabel bebas terhadap variabel terikat. Sehubungan dengan hal tersebut, maka pelaksanaan penelitian ini dilaksanakan untuk mengetahui pengaruh persepsi siswa tentang penggunaan metode pembelajaran guru $(X)$ terhadap 
aktivitas belajar (Y) pada siswa kelas XI Jurusan Pemasaran di SMK N 1 Singaraja tahun ajaran 2017/2018. Penelitian ini dilakukan di kelas XI Jurusan Pemasaran di SMK N 1 Singaraja yang beralamat di Jalan Pramuka No. 6 Singaraja.

Dalam penelitian ini data yang diperoleh merupakan data kualitatif tentang persepsi siswa dan aktivitas belajar siswa. Data kualitatif diperoleh dari penyebaran kuesioner dan lembar observasi. Adapun sumber data dalam penelitian ini adalah data primer berupa data yang diperoleh melalui kuesioner mengenai persepsi siswa tentang penggunaaan metode pembelajaran guru, dan lembar observasi mengenai aktivitas belajar siswa kelas XI Jurusan Pemasaran di SMK Negeri 1 Singaraja tahun ajaran 2017/2018. Dan data sekunder berupa data yang diperoleh dari dokumen atau catatan pihak sekolah mengenai data jumlah siswa kelas XI Jurusan Pemasaran di SMK Negeri 1 Singaraja tahun ajaran 2017/2018.

Menurut Sugiyono (2012), populasi adalah wilayah generalisasi yang terdiri atas objek atau subjek yang mempunyai kualitas atau karakteristik tertentu yang ditetapkan oleh peneliti untuk dipelajari kemudian ditarik kesimpulan. Dalam penelitian ini, populasi yang digunakan adalah seluruh siswa kelas XI Jurusan Pemasaran di SMK Negeri 1 Singaraja yang berjumlah 134 siswa.

$$
\text { Menurut Arikunto (2010:147) }
$$

"sampel adalah sebagian atau wakil populasi yang diteliti". Dalam penelitian ini teknik pengambilan sampel yang digunakan adalah proportionate random sampling. Untuk memperoleh sampel yang representatif pengambilan subjek dari setiap kelas ditentukan seimbang atau sebanding dengan banyaknya subjek dalam masing-masing kelas (Arikunto, 2010). Untuk menentukan jumlah sampel dari suatu populasi digunakan rumus slovin sebagai berikut.

$n=\frac{N}{1+N \cdot e^{2}}$

(I Imar $2005 ; 65)$

Keterangan.

$\mathrm{n}=$ ukuran sampel

$\mathrm{N}=$ ukuran populasi $\mathrm{e}=$ persen kelonggaran ketidaktelitian karena kesalahan pengambilan

Berdasarkan rumus di atas, maka jumlah sampel yang akan digunakan dalam penelitian ini dapat dihitung sebagai berikut.

$\mathrm{N}=134$

$e=5 \%$

$n=\frac{134}{1+134 \cdot(0,05)^{2}}$

134

$n=\frac{134}{1,335}$

$n=100,37453$

Berdasarkan perhitungan di atas, maka dapat diketahui jumlah sampel yang akan digunakan adalah sebesar 100 orang siswa.

Definisi operasional variabel dalam penelitian ini adalah persepsi siswa tentang penggunaan metode pembelajaran guru merupakan tanggapan siswa terhadap metode pembelajaran yang digunakan oleh guru. Indikator persepsi siswa yang diukur dalam penelitian ini, adalah pelaku persepsi, objek yang dipersepsi (penggunaan metode pembelajaran guru), dan konteks dari situasi dimana persepsi itu dilakukan (Robbins \& Judge, 2002). Aktivitas belajar adalah sikap siswa untuk ikut terlibat langsung dalam proses pembelajaran baik dengan bertanya maupun memberikan pendapat yang tercermin dalam kegiatan fisik maupun psikis. Aktivitas belajar dalam penelitian ini diamati dengan menggunakan lembar observasi. Adapun aktivitas yang akan diamati adalah visual activities oral activities, listening activities, writing activities, mental activities, dan emotional activities (Hamalik, 2009).

Metode pengumpulan data dalam penelitian ini adalah metode kuesioner digunakan untuk memperoleh data mengenai persepsi siswa tentang penggunaan metode pembelajaran guru, Kuesioner ini dibuat dalam bentuk skala likert dengan rentang skor 1-5. Untuk pernyataan positif, sangat setuju (SS) dengan skor 5 (lima), setuju (S) dengan skor 4 (empat), ragu-ragu (R) dengan skor 3 (tiga), tidak setuju (TS) dengan skor 2 (dua), dan sangat tidak setuju (STS) dengan skor 1 (satu). Sedangkan untuk 
pernyataan negatif, sangat setuju (SS) dengan skor 1 (satu), setuju (S) dengan skor 2 (dua), ragu-ragu (R) dengan skor 3 (tiga), tidak setuju (TS) dengan skor 4 (empat), sangat tidak setuju (STS) dengan skor 5 (lima).

Metode observasi digunakan untuk mengumpulkan data mengenai aktivitas belajar siswa. Dalam penelitian ini jenis observasi yang digunakan adalah observasi non partisipatif sehingga peneliti tidak ikut terlibat dalam kegiatan yang sedang diobservasi namun hanya. Metode observasi dilakukan dengan menggunakan lembar observasi.

Pengujian instrumen dalam penelitian ini yaitu, uji validitas dan reliabilitas untuk memastikan kehandalan dan tingkat kepercayaan terhadap kuesioner. Semua jenis pengujian dan analisis data dihitung dengan menggunakan SPSS 16.0 for Windows. Validitas adalah ukuran yang menunjukkan tingkat kevalidan atau kesahihan suatu instrumen. Instrumen penelitian dikatakan valid apabila koefisien korelasi antar butir lebih besar dari r-tabel dengan tingkat kesalahan alpha 0,05 (Sugiyono, 2012). Reliabilitas instrumen. Reliabilitas menunjukkan pada suatu pengertian bahwa suatu instrumen cukup dapat dipercaya untuk dapat digunakan sebagai alat pengumpul data karena instrumen tersebut sudah baik. Menurut Umar (2005) instrumen dikatakan reliabel apabila memiliki nilai alpha lebih besar dari 0,60.

Data persepsi siswa dapat dianalisis berdasarkan persentase kemunculan tiap jawaban responden mengenai persepsi siswa tentang penggunaan metode pembelajaran guru. Dalam menggolongkan kriteria persepsi siswa tentang penggunaan metode pembelajaran guru digunakan kriteria seperti yang terlihat pada tabel 1 .

Tabel 1. Kriteria Penggolongan persepsi siswa tentang penggunaan metode pembelajaran guru.

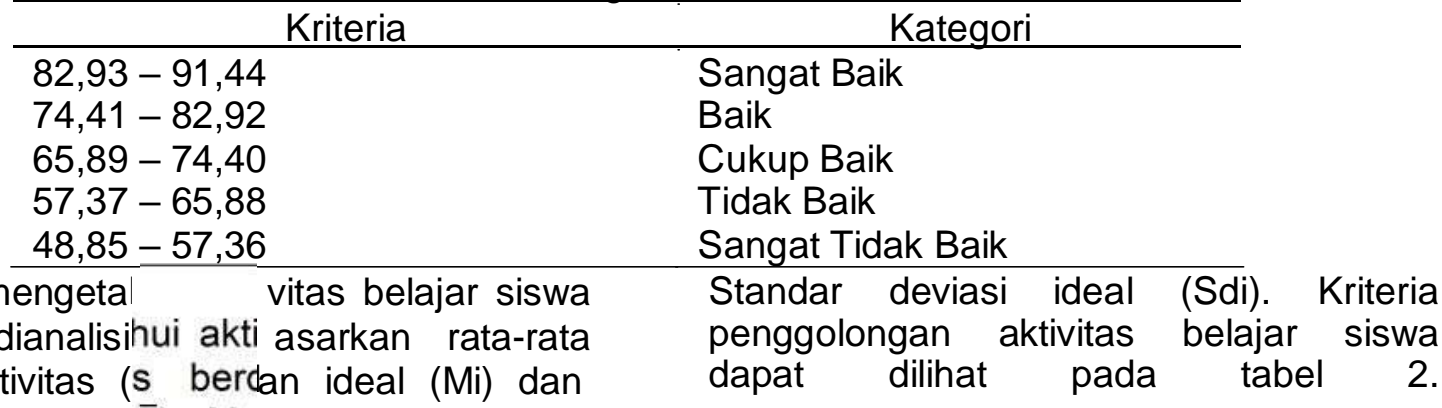

Untuk mengeta vitas belajar siswa

dapat dianalisihui akti asarkan rata-rata

skor aktivitas (s bercan ideal (Mi) dan $\bar{X})$, Me

Tabel 2. Aturan Kriteria penggolongan aktivitas belajar

\begin{tabular}{cl}
\hline \multicolumn{1}{c}{ Kriteria } & \multicolumn{1}{c}{ Katergori } \\
\hline $\bar{X} \geq \mathrm{Mi}+1,5 \mathrm{SDI}$ & Sangat Aktif \\
$\mathrm{Ml}+0.5 \mathrm{SDI} \leq \bar{X}<\mathrm{Ml}+1,5 \mathrm{SDI}$ & Aktif \\
$\mathrm{Ml}-0,5 \mathrm{SDI} \leq \bar{X}<\mathrm{Ml}+0,5 \mathrm{SDI}$ & Cukup Aktif \\
$\mathrm{Ml}-1,5 \mathrm{SDI} \leq \bar{X}<\mathrm{Ml}-0,5 \mathrm{SDI}$ & Kurang Aktif \\
$\bar{X}<\mathrm{Mi}-1,5 \mathrm{SDI}$ & Sangat kurang aktif
\end{tabular}

(diadaptasi dari Agung, 2005)

Selanjutnya ditentukan

persentase aktivitas siswa ( menjumlahkan

a-rata rat: ngan

$\bar{X}$ pedsentas emua indikator yang ada छdan -olirataratakan. Untuk menentukan aktivitas belajar siswa secara klasikal dianalisis berdasarkan
Mean ideal (Mi) dan Standar deviasi ide (Sdi) dengan mengkonversikan rata-rat persentase kedalam kriteria berikut. $\mathrm{Mi}_{\bar{a}}{ }_{\text {ta }}$ (skor tertinggi + skor terendah) $\mathrm{Sdi}==\frac{1}{2}$ skor tertinggi - skor terendah). Mean id $\frac{1}{6}$ (a) 
(Mi) adalah sebesar $\frac{1}{2} \times(24+0)=12$, Standar Deviasi Ideal (SDI) adalah sebesar $\frac{1}{6} \times(24-0)=4$. Dengan demikian dapat ditentukan kategori aktivitas belajar siswa kelas XI Jurusan Pemasaran dilihat pada tabel 3 berikut.

Tabel 3. Kriteria Penggolongan Aktivitas Belajar Siswa

\begin{tabular}{ll}
\hline Kriteria & Kategori \\
\hline $\bar{X} \geq 18$ & Sangat Aktif \\
$14 \leq \bar{X}<18$ & Aktif \\
$10 \leq \bar{X}<14$ & Cukup Aktif \\
$6 \leq \bar{X}<10$ & Kurang Aktif \\
$\bar{X}<6$ & Sangat Kurang Aktif
\end{tabular}

Dalam penelitian ini pengujian hipotesis menggunakan uji parsial (Uji t) untuk mengetahui pengaruh masing-masing variabel independen terhadap variabel dependen. Sebelum uji hipotesis dilakukan terlebih dahulu dilakukan uji normalitas dan uji linearitas. Pengujian hipotesis (uji t) menggunakan bantuan program SPSS for windows versi 16. Rancangan pengujian hipotesis dalam penelitian ini adalah menolak $\mathrm{H}_{0}$ dan menerima $\mathrm{H}_{\mathrm{a}}$ apabila thitung $>t_{\text {tabel }}$ dan $p$ - value $<\alpha$, berarti persepsi siswa tentang penggunaan metode pembelajaran guru berpengaruh signifikan terhadap aktivitas belajar siswa kelas XI Jurusan Pemasaran di SMK Negeri 1 Singaraja tahun ajaran 2017/2018 dan menerima $\mathrm{H}_{0}$ dan menolak $\mathrm{H}_{\mathrm{a}}$ apabila $\mathrm{t}_{\text {hitung }}<$ $t_{\text {tabel }}$ dan $p$-value $>\alpha$, berarti persepsi siswa tentang penggunaan metode pembelajaran guru tidak berpengaruh signifikan terhadap aktivitas belajar siswa kelas XI Jurusan Pemasaran di SMK Negeri 1 Singaraja tahun lajaran 2017/2018.

\section{HASIL DAN PEMBAHASAN Hasil}

Berdasarkan hasil yang diperoleh dari penelitian mengenai data persepsi siswa kelas XI Jurusan Pemasaran tentang penggunaan metode pembelajaran guru pengetahuan produk di SMK N 1 Singaraja, maka diperoleh hasil kategori persepsi siswa yaitu, banyaknya siswa yang memiliki persepsi sangat baik, baik, cukup baik, tidak baik, dan sangat tidak baik pada kelas XI Jurusan Pemasaran dapat dilihat pada tabel

Tabel 4. Persepsi siswa tentang penggunaan metode pembelajaran guru

\begin{tabular}{ll}
\hline Kategori & Siswa \\
\hline Sangat Baik & 7 \\
Baik & 29 \\
Cukup Baik & 39 \\
Tidak Baik & 19 \\
Sangat Tidak Baik & 6 \\
Jumlah & 100 \\
\hline
\end{tabular}

Persentase
7
29
39
19
6
100

Berdasarkan tabel diatas dapat diketahui bahwa dari 100 siswa, sebanyak 7 orang siswa memiliki persepsi yang sangat baik tentang penggunaan metode pembelajaran guru, 29 orang siswa memiliki persepsi yang baik, 39 siswa memiliki persepsi yang cukup baik, terdapat 19 siswa yang memiliki persepsi yang tidak baik, dan sebanyak 6 siswa yang memiliki persepsi yang sangat tidak baik tentang penggunaan metode pembelajaran guru. Sehingga dapat disimpulkan bahwa persepsi siswa kelas XI Jurusan Pemasaran tentang penggunaan metode pembelajaran guru secara keseluruhan berada dalam kategori cukup baik yang 
ditunjukkan oleh persentase tertinggi yaitu sebesar $39 \%$.

Berdasarkan hasil penelitian di SMK $N 1$ Singaraja diperoleh data tentang aktivitas belajar siswa kelas XI Jurusan Pemasaran pada mata pelajaran pengetahuan produk dapat dilihat pada tabel 5 .

Dari tabel 5 dapat diketahui bahwa tidak ada aktivitas belajar siswa yang berada dalam kategori kurang aktif maupun sangat kurang aktif. Sebanyak 30 orang siswa tergolong dalam cukup aktif, sebanyak 69 orang siswa berada pada kategori aktif, dan untuk kategori sangat aktif hanya terdapat 1 orang siswa. Berdasarkan persentase tertinggi dapat disimpulkan bahwa aktivitas belajar pengetahuan produk kelas XI Jurusan Pemasaran di SMK N 1 Singaraja berada dalam kategori aktif dengan persentase sebesar $69 \%$.

Tabel. 5 Sebaran aktivitas belajar siswa

\begin{tabular}{ll}
\hline Kategori & Siswa \\
\hline Sangat Aktif & 1 \\
Aktif & 69 \\
Cukup Aktif & 30 \\
Kurang Aktif & 0 \\
Sangat Kurang Aktif & 0 \\
Jumlah & 100 \\
\hline hasil dari pengujian pengaruh \\
siswa tentang penggunaan
\end{tabular}

Persentase
1
69
30
0
0
100

aktivitas belajar siswa kelas $\mathrm{XI}$ Jurusan Pemasaran pada mata pelajaran pengetahuan produk tampak pada tabel 6 .

Tabel 6. Hasil uji statistik (Uji t) Coefficients $^{\mathrm{a}}$

\begin{tabular}{|c|c|c|c|c|c|c|}
\hline & & Unstandardized & Coefficients & $\begin{array}{c}\text { Standardiz } \\
\text { ed } \\
\text { Coefficient } \\
\mathrm{s} \\
\end{array}$ & & \\
\hline Model & & $\mathrm{B}$ & Std. Error & Beta & $\mathrm{t}$ & Sig. \\
\hline \multirow[t]{2}{*}{1} & (Constant) & 23,490 & 4,692 & & 5,007 &, 000 \\
\hline & $\begin{array}{l}\text { Persepsi } \\
\text { Penggunaan Metode } \\
\text { Pembelajaran Guru }\end{array}$ & ,918 & ,065 & ,817 & 14,030 &, 000 \\
\hline
\end{tabular}

a. Dependent Variable: Aktivitas Belajar Siswa

Berdasarkan hasil analisis uji t pada tabel 4.3 terlihat bahwa nilai $t_{\text {hitung }}$ adalah sebesar 14,030 dan memiliki nilai signifikansi sebesar $0,000<0,05$. Dengan demikian, hipotesis $\mathrm{H}_{0}$ ditolak. Hal ini menunjukkan bahwa persepsi siswa tentang penggunaan metode pembelajaran guru memiliki pengaruh yang signifikan terhadap aktivitas belajar siswa. Adapun besarnya pengaruh persepsi siswa tentang penggunaan metode pembelajaran tampak pada tabel 7 sebagai

Tabel 7 Hasil Uji Koefision Determinasi (Adjusted $R$ Square) Model Summary ${ }^{b}$

\begin{tabular}{|c|c|c|c|c|}
\hline Model & $\mathrm{R}$ & R Square & $\begin{array}{l}\text { Adjusted R } \\
\text { Square }\end{array}$ & $\begin{array}{l}\text { Std. Error of } \\
\text { the Estimate }\end{array}$ \\
\hline 1 & $817^{a}$ &, 668 &, 664 & 5,39155 \\
\hline
\end{tabular}




\section{a. Predictors: (Constant), Persepsi Penggunaan Metode}

Pembelajaran Guru

\section{b. Dependent Variable: Aktivitas Belajar Siswa}

Berdasarkan tabel di atas dapat diketahui besarnya nilai $R$ Square $\left(R^{2}\right)$ adalah 0,668 atau $66,8 \%$. Hal ini menunjukkan bahwa besarnya pengaruh variabel persepsi siswa terhadap aktivitas belajar adalah sebesar $66,8 \%$. Sedangkan sisanya sebesar $33,2 \%$ disebabkan oleh variabel lain di luar penelitian ini.

\section{Pembahasan}

Berdasarkan hasil penelitian dapat diketahui bahwa siswa kelas XI Jurusan Pemasaran memiliki persepsi yang berbeda-beda tentang penggunaan metode pembelajaran guru. Persepsi seseorang dengan orang lainnya dapat sangat jauh berbeda meskipun objek yang dipersepsi sama. Menurut Walgito (2010) perbedaan persepsi siswa dipengaruhi oleh karakteristik yang berbeda pada masingmasing siswa. Begitupun dengan siswa pada kelas XI Jurusan Pemasaran tentu memiliki karakteristik yang berbeda pula sehingga persepsi masing-masing siswa pun berbeda terhadap penggunaan metode pembelajaran guru. Terdapat siswa yang memiliki persepsi yang baik tetapi terdapat juga siswa yang memiliki persepsi yang kurang baik.

Walgito (2010:97) menyatakan bahwa "persepsi merupakan suatu proses yang didahului oleh proses penginderaan, yaitu merupakan proses diterimanya stimulus oleh individu melalui alat indera atau juga disebut proses sensoris. Proses ini diteruskan oleh stimulus dan dilanjutkan ke proses persepsi". Siswa dapat menilai metode yang diterapkan oleh guru dari proses penginderaan. Siswa menyadari baik atau kurang baiknya metode yang diterapkan oleh guru. Semakin baik metode yang diterapkan oleh guru, maka akan menimbulkan persepsi yang baik dari siswa. Sebaliknya, apabila metode yang digunakan guru kurang baik maka akan menimbulkan persepsi yang kurang baik juga dari siswa.

Dalam hal ini untuk menumbuhkan persepsi siswa yang baik tentang metode pembelajaran guru harus didukung oleh kemampuan guru untuk dapat menerapkan metode pembelajaran yang menarik dan menyenangkan sesuai dengan tujuan pembelajaran serta karakteristik siswa sehingga siswa tertarik untuk mengikuti pembelajaran dan tercipta kegiatan belajar mengajar yang aktif dan menyenangkan bagi siswa.

Aktivitas belajar siswa kelas XI Jurusan Pemasaran juga berbeda-beda terdapat siswa yang sangat aktif dalam mengikuti kegiatan pembelajaran akan tetapi terdapat juga siswa yang kurang aktif dalam mengikuti kegiatan belajar mengajar. Menurut Djamarah \& Aswan (2006:81) "aktivitas belajar anak didik tidak selalu sama, tinggi rendahnya aktivitas belajar dipengaruhi oleh penggunaan metode pembelajaran". Dalam mengajar guru selalu menggunakan berbagai metode pembelajaran, baik itu ceramah, diskusi, tanya jawab, maupun penugasan. Penggunaan metode pembelajaran yang berbeda-beda ini tentu akan menghasilkan aktivitas belajar yang berbeda pula. Saat guru nmenggunakan metode ceramah, siswa yang dapat berkonsentrasi dengan baik akan aktif dalam mendengarkan, apabila guru menggunakan metode tanya jawab, siswa yang mampu mengajukan pertanyaan dan ingin menyampaikan pendapat akan aktif dalam bertanya, menjawab, maupun menyampaikan pendapat. Pembelajaran yang aktif akan terjadi apabila seluruh siswa mampu berpartisipasi aktif dalam kegiatan pembelajaran tidak hanya melibatkan beberapa orang siswa saja.

Meskipun aktivitas belajar siswa kelas XI Jurusan Pemasaran sudah tergolong aktif, guru dapat lebih mengoptimalkan lagi aktivitas belajar siswa agar seluruh siswa dapat berpartisipasi secara aktif dalam kegiatan pembelajaran. Adapun upaya yang dapat dilakukan oleh guru untuk meningkatkan aktivitas belajar siswa, yaitu dalam mengajar guru harus senantiasa bersemangat, penuh percaya diri dan antusias sehingga siswa merasa dekat dan nyaman dalam mengikuti pelajaran. 
Sebelum memulai pelajaran, guru harus memberitahukan kepada siswa tujuan dari pembelajaran yang mereka ikuti, menyediakan fasilitas, media, dan sumber belajar yang mendukung proses pembelajaran, memberikan siswa apresiasi atau pujian pada saat siswa berhasil menjawab pertanyaan maupun mendapatkan skor terbaik, konsisten dalam menerapkan aturan yang telah dibuat sebelumnya, dan memberikan siswa reinforcement atau penguatan yang bertujuan untuk memberikan umpan balik kepada siswa sehingga siswa dapat lebih memahami materi yang disampaikan.

Berdasarkan hasil penelitian terdapat pengaruh yang signifikan antara persepsi siswa tentang penggunaan metode pembelajaran terhadap aktivitas belajar. Hasil penelitian ini sejalan dengan pendapat Suryabrata (2004) yang menyatakan bahwa ada delapan faktor psikologi yang mempengaruhi aktivitas belajar, yaitu perhatian, pengamatan, persepsi, fantasi, ingatan, berpikir, perasaan, dan motif.

Dalam mengajar diperlukan penggunaan metode pembelajaran yang menarik dan menyenangkan agar siswa tidak merasa bosan dan jenuh dalam belajar. Apabila telah tercipta suasana belajar yang menyenangkan, maka akan menimbulkan persepsi yang baik dari dalam diri siswa. Saputri (2016) menyatakan bahwa jika persepsi siswa tentang metode mengajar guru baik, maka aktivitas belajar siswa juga akan meningkat. Persepsi siswa yang baik terhadap penggunaan metode pembelajaran guru akan terlihat dari perilaku siswa saat mengikuti kegiatan belajar mengajar seperti aktif dalam memperhatikan penjelasan dari guru, aktif dalam bertanya maupun menyampaikan pendapat dan aktif berfatisipasi dalam kegiatan belajar mengajar.

\section{SIMPULAN DAN SARAN Simpulan}

Berdasarkan rumusan masalah dan pembahasan, dapat disimpulkan persepsi siswa kelas XI Jurusan Pemasaran tentang penggunaan metode pembelajaran guru tergolong dalam kategori cukup baik. Hal ini dapat dilihat dari jumlah persentase tertinggi yaitu sebesar 39\%, sedangkan aktivitas belajar siswa kelas XI Jurusan Pemasaran berada dalam kategori aktif yang ditunjukkan dengan persentase tertinggi sebesar 69\%, dan terdapat pengaruh yang signifikan antara persepsi siswa tentang penggunaan metode pembelajaran guru terhadap aktivitas belajar pada siswa kelas XI Jurusan Pemasaran di SMK N 1 Singaraja tahun ajaran 2017/2018. Hal ini ditunjukkan dengan nilai $t_{\text {hitung }}$ adalah sebesar 14,030 dan memiliki nilai signifikansi sebesar 0,000 $<0,05$

\section{Saran}

Agar siswa tidak merasa bosan dalam belajar dan tercipta kegiatan belajar yang aktif sebaiknya guru menggunakan metode pembelajaran yang lebih bervariasi. Apabila guru menggunakan metode ceramah, guru harus berusaha menjadikan metode ceramah tersebut menjadi menarik bagi siswa, sehingga siswa dapat berkonsentrasi dalam mendengarkan materi yang disampaikan. Apabila guru menggunakan metode tanya jawab, guru harus berusaha untuk melibatkan seluruh siswa agar aktif dalam proses pembelajaran. Dalam menyampaikan materi agar siswa lebih mudah mengerti dan memahami materi yang disampaikan, guru hendaknya menyampaikan materi dengan konstektual yaitu selalu memberikan contoh nyata terkait materi kepada siswa. Apabila guru telah menggunakan metode pembelajaran yang menarik dan menyenangkan maka akan menumbuhkan persepsi yang baik juga di dalam diri siswa. Persepsi yang baik akan mempengaruhi aktivitas belajar siswa dan juga siswa akan termotivasi untuk terlibat secara aktif dalam kegiatan belajar mengajar. Sehingga tercipta suasana belajar yang aktif dan menyenangkan di dalam kelas.

\section{DAFTAR PUSTAKA}

Agung, Gede. 2005. Metodologi Penelitian Pendidikan. Singaraja : Undiksha

Arikunto, S. 2010. Prosedur Penelitian: Suatu Pendekatan Praktik. Edisi Revisi. Jakarta: PT. Rineka Cipta. 
Djamarah, BS \& Aswan. Z. 2006. Strategi Belajar Mengajar. Edisi Revisi. Jakarta: PT Rineka Cipta

Hamalik, Oemar. 2009. Proses Belajar Mengajar. Cetakan ke-10. Jakarta: PT. Bumi Aksara

Robbins SP, \& Judge. 2002. Perilaku Organisasi. Jakarta: Salemba Empat

Sanjaya, Wina. 2011. Strategi Pembelajaran Berorientasi Standar Proses Pendidikan. Jakarta: Kencana Prenasa Media Grup

Saputri, Ajeng Nabila Dini. 2016. Pengaruh Persepsi Siswa Tentang Metode Mengajar Guru dan Motivasi Belajar Siswa Terhadap Hasil Belajar Ekonomi Akuntansi Melalui Aktivitas Belajar Pada Siswa Kelas XII IPS SMA NEGERI 2 Pringsewu Tahun Pelajaran 2015/2016. Skripsi tidak diterbitkan. Universitas Lampung.

Sardiman, A.M. 2011. Interaksi \& Motivasi Belajar Mengajar. Jakarta: Rajawali Pers

Slameto. 2003. Belajar dan Faktor - Faktor yang mempengaruhinya. Jakarta: PT Rineka Cipta

Sudjana. Nana. 2005. Dasar-dasar Proses belajar mengajar. Bandung: Sinar Baru Algesindo

Sugiyono. 2012. Statistika Untuk Penelitian. Bandung: Alfabeta

Suryabrata, Sumadi. 2004. Psikologi Pendidikan. Jakarta: PT. RajaGrafindo Persada.

Umar, Husein. 2005. Metode Penelitian untuk Skripsi dan Thesis Bisnis. Jakarta: PT Raja Grafindo Persada.
Walgito, Bimo. 2010. Pengantar Psikologi Umum. Yogyakarta: CV. Andi Offset 